\title{
KONFLIK AGRARIA YANG TAK PERNAH REDA
}

\author{
Mukmin Zakie \\ Dosen Fakultas Hukum Universitas Islam Indonesia \\ Jalan Kaliurang KM. 14.4, Umbulmartani, Ngemplak, Kabupaten Sleman \\ Email: zakie_fh@uii.ac.id
}

\begin{abstract}
The ideal goal to be achieved by this country when it declared Law Number 5 of 1960 on the Basic Regulation of Agrarian is the prosperity of society, especially farmers and there is no more conflict. Conflicts before the law is one of them for their legal dualism governing agrarian question. Unification law which regulates the keagrarian expected to answer and give a solution to the conflict over the years. It turns out that the opposite is true, more and more regulations issued with respect to agrarian, it further adds new problems. Changes in the pattern and kareteristik conflict evolves with people's lives, mindset and outlook changed to agrarian particularly land, requires also look for a pattern resolution of the conflict. This paper attempts to it.
\end{abstract}

\section{Keywords: Agrarian Conflict, Prosperity of Society, Legal Dualism}

\begin{abstract}
Abstrak
Tujuan ideal yang ingin dicapai Republik ini ketika dicanangkan Undang-undang Nomor 5 Tahun 1960 tentang Peraturan Dasar Pokok-pokok Agraria adalah kemakmuran masyarakat terutama kaum petani dan tidak ada lagi konflik. Konflik yang terjadi sebelum adanya undang-undang tersebut salah satunya karena adanya dualisme hukum yang mengatur soal agraria. Adanya unifikasi hukum yang mengatur soal keagrarian diharapkan mampu menjawab dan memberikan solusi atas konflik selama ini. Ternyata yang terjadi adalah sebaliknya, semakin banyak peraturan yang dikeluarkan berkenaan dengan agraria, justru semakin menambah persoalan baru. Perubahan pola dan kareteristik konflik berkembang seiring dengan berkembangnya kehidupan masyarakat, pola pikir dan pandangan yang berubah terhadap agrarian terutama tanah, mengharuskan pula mencari pola penyelesaian konflik tersebut. Tulisan ini mencoba untuk itu.
\end{abstract}

\section{Kata Kunci: Konflik Agraria, Kemakmuran Masyarakat, Dualisme Hukum}

\section{A. Pendahuluan}

Reformasi politik yang terjadi lebih dari satu dasawarsa yang lalu telah membawa banyak perubahan dalam kehidupan berbangsa di Indonesia. Menguatnya masyarakat sipil telah menjadikan munculnya berbagai aspirasi masyarakat, baik yang terkait dengan tata pemerintahan maupun terkait dengan berbagai pranata sosial. Tidak semua aspirasi dapat terakomodasi secara proporsional, sehingga menimbulkan berbagai ketegangan sosial.

Permasalahan terkait dengan sumber daya agraria adalah salah satu sektor yang secara jelas menunjukkan adanya ketegangan sosial tersebut. Berbagai kerusuhan massa muncul dan secara vis a vis berhadapan dengan pemerintah dan pihak swasta yang bergerak dalam bidang 
sumber daya agraria. Menyeruaknya kasus-kasus sengketa agraria seperti sengketa lahan antara masyarakat adat dengan PT Barat Selatan Makmur Investindo (BSMI) di Mesuji, Lampung ${ }^{1}$, sengketa agraria di bidang pertambangan emas antara masyarakat Pape dengan PT Sumber Mineral Nusantara (SMN) di Bima, Nusa Tenggara Barat, ${ }^{2}$ sengketa agraria di PTPN II di Sumatera Utara, ${ }^{3}$ adalah di antara kasus sengketa yang terjadi. Bahkan jika dilihat dari banyaknya kasus yang terjadi dengan proporsi jenis lahan yang disengketakan, data yang ada cukup mencengangkan:

Secara garis besar, sengketa lahan secara umum dapat dikatakan sebagai konflik untuk memperebutkan hak atas lahan, baik lahan pertanian, perkebunan, maupun tambang, antara rakyat yang selama ini menjadi penggarap, dengan pihak pemerintah serta swasta yang terkait dengan pengelolaan lahan tersebut. ${ }^{4}$

Politik hukum agraria di Indonesia juga tidak dapat dilepaskan keterkaitannya dengan berbagai permasalahan tersebut di atas. Undang-Undang Nomor 5 tahun 1960 tentang Peraturan Dasar Pokok-Pokok Agraria, atau yang lebih dikenal dengan UUPA memberikan kekuasaan yang sangat luas kepada negara atas sumber daya agraria dengan konsep yang dikenal dengan "hak menguasai oleh Negara" (HMN). Semula konsep ini dibuat untuk menghapus konsep domain verklaring yang diterapkan oleh pemerintah kolonial untuk "merebut" tanah yang dikuasi masyarakat hukum adat. Pada perkembangannya, HMN ini dalam penerapannya hampir sama dengan konsep domain verklaring pada masa kolonial. ${ }^{5}$

Hingga saat ini, konflik ini belum dapat terselesaikan dengan baik, bahkan cenderung mengalamai stagnasi dalam proses penyelesaiannya. ${ }^{6}$ Hal ini dikarenakan permasalahan ini memiliki tingkat kompleksitas yang tinggi, di mana permasalahannya terkait dengan hukum, politik, ekonomi serta hak-hak masyarakat lokal. Pada gilirannya, dampak yang terjadi adalah terabaikannya hak-hak rakyat yang kenyataannya telah mengelola tanah atau lahan tertentu secara turun temurun.

\section{B. Pembahasan}

\section{Arti Pentingnya Tanah bagi Kehidupan}

Tanah adalah karunia dari Tuhan Yang Maha Esa kepada umat manusia di muka bumi. Tanah menjadi kebutuhan dasar manusia. Sejak lahir sampai meninggal dunia, manusia membutuhkan tanah untuk tempat tinggal dan sumber kehidupan. Secara kosmologis, tanah adalah tempat manusia tinggal, tempat bekerja dan hidup, tempat dari mana mereka berasal

Kompas, 17 Desember 2011

Gatra News, 28 Januari 2012

Republika, 14 Desember 2011

4 Kalo, Syafruddin. 'Di Bawah Cengkeraman Kapitalisme: Konflik Status Tanah Jaluran Antara Onderneming Dan Rakyat Penunggu Di Sumatra Timur Jaman Kolonial,’ USU Digital Library. Diakses 10 Maret 2012.

5 Haedar Laudjeng, dan Arimbi. HP, Bayang-Bayang Culturstelsel dan Domein Verklaring dalam Praktik Politik Agraria, WALHI. Jakarta. 1997

6 Kalo, Syafruddin. 'Perbedaan Persepsi Mengenai Penguasaan Tanah Dan Akibatnya Terhadap Masyarakat Petani Di Sumatera Timur: Pada Masa Kolonial Yang Berlanjut Pada Masa Kemerdekaan, Orde Baru Dan Reformasi,' USU Digital Library. Diakses 1 Maret 2012. 
dan akan kemana pula mereka pergi. Dalam hal ini tanah mempunyai dimensi ekonomi, sosial, kultural politik dan ekologis.

Dalam sejarah peradaban umat manusia, tanah merupakan faktor yang paling utama dalam menentukan produksi setiap fase peradaban. Tanah tidak hanya mempunyai nilai ekonomis tinggi, tetapi juga nilai filosofis, politik, sosial, dan kultural. Tidak mengherankan jika tanah menjadi harta istimewa yang tidak henti-hentinya memicu berbagai masalah sosial yang kompleks dan rumit.

Sebagai sumber agraria yang paling penting, tanah merupakan sumber produksi yang sangat dibutuhkan sehingga ada banyak kepentingan yang membutuhkannya. Perkembangan penduduk dan kebutuhan yang menyertainya semakin tidak sebanding dengan luasan tanah yang tidak pernah bertambah.

Peningkatan penggunaan tanah penyebab terjadinya bermacam-macam corak dan bentuk hubungan antara manusia dengan tanah, yang sekaligus menyebabkan terjadinya perkembangan dalam bidang hukum tanah secara normatif, baik pada hukum tertulis maupun tidak tertulis. Perkembangan itu ikut mempengaruhi pandangan masyarakat terhadap tanah, apakah dari segi pemilikan, penguasaan maupun penggunaannya. ${ }^{7}$

Hal ini terlihat apabila dilakukan pengamatan terhadap perubahan masyarakat agraris menjadi masyarakat industri. Pada masyarakat agraris hubungan antara manusia dengan tanahnya bersifat religio-magis-kosmis, iaitu hubungan antara manusia dengan tanah yang menonjolkan penguasaan kolektif. ${ }^{8}$ Pada masyarakat yang mulai meninggalkan ketergantungan kepada sektor agraris (menuju masyarakat industri), hubungan manusia dengan tanah merujuk kepada hubungan yang bersifat individualis dan berorientasi ekonomis. Perubahan bentuk hubungan tersebut semakin jelas dengan pengembangan hukum tanah, terutama hukum tertulis yang lebih cenderung menyetujui kepemilikan secara individu. ${ }^{9}$

Tanah bagi kehidupan manusia mempunyai arti yang sangat penting untuk memenuhi kebutuhan hidupnya. Sejak lahir manusia sudah 'dikenalkan' arti pentingnya tanah, seterusnya dalam mengarungi kehidupan ini seseorang tidak pernah terpisahkan dari 'urusan' tanah. Wajar sajalah kemudian dikatakan secara turun temurun manusia sudah terkondisi agar selalu berinteraksi dengan tanah sebagai tempat ia hidup.

Berlakunya pepatah yang menyatakan sedhumuk batuk senyari bumi di tohi pati, merupakan suatu ungkapan betapa berartinya tanah bagi seseorang, sampai-sampai nyawa akan dipertaruhkan apabila ada yang mencoba mengusik apalagi merampasnya. Bagi bangsa Indonesia tanah bukan sekedar bernilai ekonomis tetapi juga mengandung nilai/ikatan magis yakni dengan ditanamnya ari-ari (placenta) sebagai sumber kehidupan ketika berada dalam rahim ibu. Mengandung nilai historis, psikologis dan nilai monumental. ${ }^{10}$

\footnotetext{
Mukmin Zakie, Kewenangan Negara dalam Pengadaan Tanah bagi Kepentingan umum di Indonesia dan Malaysia, Buku Litera Yogyakarta, 2013, hlm. 4

John Salindeho, Masalah Tanah Dalam Pembangunan, Sinar Grafika, Jakarta, 1987, hlm. 11

${ }^{10}$ Mukmin Zakie, Op Cit, hlm. 2
}

9 ibid 
Kadar pertambahan jumlah penduduk yang tinggi, sedangkan keadaan tanah tidak bertambah, menyebabkan kebutuhan penduduk terhadap tanah menjadi tinggi. Meskipun masih banyak tanah yang belum digarap, namun permintaan tanah yang berlebihan oleh petani-petani yang tidak memiliki tanah menyebabkan masalah tanah begitu kompleks dan sangat rumit. Kerumitan ini ditambah dengan masalah administrasi pertanahan yang belum terpadu. ${ }^{11}$ Masalah tanah menjadi rawan konflik dikarnakan adanya pemilikan yang tidak seimbang. ${ }^{12}$ Dengan itu, manusia semakin menggiatkan usahanya mendapatkan tanah untuk mencapai tujuan masing-masing dalam memanfaatkan tanah. Jika usaha itu tidak diawasi dengan cara-cara tertentu, penyerobotan atau okupasi tanah dan pengambilan tanah menjadi begitu jelas dan mungkin akan terjadi pertumpahan darah, monopoli, penelantaran (dalam arti kata tanah tidak dimaksimumkan penggunaan atau manfaatnya), ketidak-adilan dalam menggunakan atau memanfaatkan tanah, ruang angkasa dan sejenisnya. ${ }^{13}$

Tanah merupakan modal dasar bagi kehidupan manusia. Sebagai sebuah modal dasar, maka tanah memiliki dua fungsi: fungsi produksi dan fungsi non produksi. Kebutuhan akan penggunaan tanah tersebut sering berbenturan, mengingat bahwa terdapatnya jumlah luas tanah yang terbatas, pada sisi yang lain terdapat ledakan pertumbuhan penduduk.

Tanah menjadi sangat penting ketika terdapat dua makna atas arti penting tanah. Tanah dapat diartikan sebagai nilai ekonomi, pada sisi yang lain tanah diartikan memiliki kegunaan non ekonomi (nilai religio-magis dan sosial tanah). Pada saat itulah memunculkan konflik tanah yang tampaknya tidak mudah untuk dipecahkan. Sejarah membuktikan bahwa terjadinya konflik, pertumpahan darah sejak masa lalu hingga perang Irak dan semua peperangan di muka bumi ini lebih disebabkan perebutan atas penguasaan sebidang tanah. ${ }^{14}$

Seorang sarjana dari Barat mengibaratkan tanah sebagai sepotong intan atau batu permata yang memiliki banyak sisi, kadang tanah dipandang sebagai ruang, alam, faktor produksi, barang-barang konsumsi, milik, dan modal. Di samping itu ada juga yang memandang tanah sebagai benda yang berkaitan dengan sang pencipta (Tuhan), berkaitan dengan masyarakat yang menimbulkan pandangan bahwa tanah sebagai kosmos, dan pandangan bahwa tanah adalah sebagai tabungan (saving) serta menjadikan tanah sebagai aset (kekayaan). ${ }^{15}$

Pentingnya keberadaan tanah bagi kehidupan manusia akan membentuk hubungan yang sangat erat antara manusia dengan tanahnya. Dalam hubungan antara manusia dengan tanah akan terbentuk suatu dialektik yang memberi 'warna' tersendiri bagi kehidupan manusia dalam masyarakat. Hubungan ini dapat menentukan dan mempengaruhi seluruh struktur

11 Perlembagaan Persekutuan, Seksyen 2 Senarai II-Senarai Negeri, lih Kanun Tanah Negara 1965, seksyen 40.

12 Chamhuri Siwar, 'Penyusunan Semula Masyarakat Melalui Reformasi Tanah' dalam ; Isu Ekonomi, Sosial Dan Politik Malaysia : Kumpulan Esei Dewan Masyarakat 1975-1979, Dewan Bahasa dan Pustaka Kementerian Pelajaran Malaysia, Kuala Lumpur, 1983, hlm. 48.

13 Abdul Aziz Hussin, Undang-undang Tanah Lesen Pendudukan Sementara dan Permit, Dewan Bahasa dan Pustaka, Kuala Lumpur, Ctk. 1, 1996, hlm. 1

${ }_{14}$ Mukmin Zakie, Op Cit, hlm. 5

15 Releigh Barlowe, Land Resource Economics: The Economics of Real Estate, Prentice-Hall Inc. New Jersey, 1978, hlm. 10 
hubungan manusia dengan manusia, manusia dengan masyarakat,bahkan hubungan antara manusia dalam suatu negara. ${ }^{16}$

Seiring dengan perkembangan kebudayaan manusia, pengaturan penguasaan tanah pada mulanya ditemukan dalam bentuk hukum tidak tertulis, yang berkembang dan dibentuk bersama oleh masyarakat tersebut, dan berlaku serta dipatuhi hanya pada kesatuan masyarakatnya. Peraturan demikian di dalam literatur hukum di Indonesia dikenal dengan hukum adat dan aturan adat tentang penguasaan tanah. ${ }^{17}$

Hukum Tanah muncul sebagai sebuah jawaban atas kepentingan manusia terhadap tanah. Hukum memberikan batas atas kepemilikan tanah. Tanah tidak dapat dilepaskan pengaturannya pada hubungan yang bersifat privat/individu murni, akan tetapi tanah merupakan sebuah domein negara. Tanah menjadi sumber bagi pencapaian kemakmuran sebuah bangsa, dan ketika berbicara bangsa maka negara berperan secara aktif dalam pengelolaan dan pemanfaatan tanah. Pasal 33 (3) UUD 1945 memberikan landasan juridis atas penguasaan sumber daya alam, salah satunya adalah tanah. Inilah konsep dasar hak menguasai negara atas tanah yang bertujuan untuk mencapai sebuah taraf kemakmuran bagi rakyat Indonesia. Akan tetapi pada dataran implementasi yang terjadi justru banyak muncul konflik tanah.

Dianto Bachriadi dan Anton Lucas ${ }^{18}$ menyimpulkan bahwa sistem pengelolaan tanah dimasa orde baru hanya menguntungkan penguasa dan kroninya yang hal ini telah menyebabkan banyak petani yang kehilangan hak dan akses atas tanah. Akibatnya adalah dalam 20 tahun terkahir jumlah sengketa tanah di Indonesia meningkat tajam dan sengketa ini sering kali berubah menjadi konflik terbuka antara petani dan aparat keamanan.

Konflik tanah tidak mudah untuk diselesaikan. Hal ini dapat difahami mengingat dimensi penguasaan atas tanah bukan sekadar penguasaan atas sebidang objek fisik berupa tanah secara kasat mata, tetapi juga sebuah keyakinan bahwa tanah mengandung nilai religi magis yang kuat di kalangan masyarakat. ${ }^{19}$ Masuknya investasi yang memandang tanah sebagai sebuah objek fisik bernilai ekonomi semata-mata akan berhadapan dengan masyarakat yang masih memandang bahwa tanah tidak sekedar bernilai ekonomis tetapi mengandung nilai sakral, karena di tanah tersebut ia dilahirkan, orang tua dimakamkan, harga diri dimunculkan dalam bentuk penguasaan atas tanah. Pendek kata ada nilai monumental atas tanah tersebut.

Noer Fauzi ${ }^{20}$ berdasarkan kajian yang diilakukannya menyimpulkan bahwa pembaruan hukum agraria yang selama ini dilakukan belum memadai dikarnakan tidak memberikan perhatian yang konprehensip terhadap berbagai aspek agraria misalnya terkait dengan hal-hal

16 B. Ter Haar, Bzn, Terjemahan Schiller, A.A. \& E.A. Hoebel, 1962. Adat Law In Indonesia, Bharata, Jakarta, hlm. 55.

17 Hermayulis, 'Penerapan Hukum Pertanahan dan Pengaruhnya Terhadap Hubungan Kekerabatan Pada Sistem Kekerabatan Matrilineal Minangkabau Di Sumatera Barat', Disertasi, PPS-UI, 1999. hlm. 4

18 Dianto Bachriadi, dan Anton Lucas, Merampas Tanah Rakyat,Kasus Tapos dan Cimacan, Kepustakaan Populer Gramedia, Jakarta, 2001, hlm. 80

19 Mukmin Zakie, "Undang-Undang Pengambilan Tanah Di Indonesia Dan Di Malaysia (Suatu Kajian Perbandingan)", Desertasi Doktor Falsafah Fakulti Undang-Undang, Universiti Kebangsaan Malaysia, 2011, hlm. 15

${ }^{20}$ Noer Fauzi, Bersaksi untuk Pembaharuan Agraria, dari Tuntutan Lokal hingga Kecenderungan Global, Insist Press, Yogyakarta, 2003, hlm.32 
pendaftaran dan pengurusan klaim-klaim masyarakat dengan tanah yang hilang akibat pelanggaran HAM.

Untuk itu diperlukan pembaharuan hukum agraria yang lebih konprehensif mengakomodasi berbagai aspek yang terkait. Bahkan keberadaan berbagai masyarakat adat dengan dengan hak atas tanah perlu dicermati secara sungguh-sungguh.

Kehadiran masyarakat adat sebagai masyarakat 'asli' Indonesia sejak dahulu adalah suatu kenyataan sosial. Masyarakat adat tidak tumbuh dan berkembang dengan idealisme politik yang utopis. Eksistensinya sudah ada sejak ratusan tahun, yang ditandai adanya berbagai kelompok manusia dengan tatanan kehidupan dalam sebuah teritorial tertentu. Pergaulan mereka selalu didasarkan pada filosofi hidup yang sudah mereka tentukan, yang umumnya ditandai dengan adanya kebersamaan dan kekeluargaan. ${ }^{21}$

Mukmin Zakie ${ }^{22}$ berpendapat bahwa ada dua kemungkinan mengapa pengaturan masyarakat adat dalam hukum Negara dari dulu sampai kini masih belum jelas. Pertama pemerintah dalam kapasitas sebagai pemegang arah kebijakan tidak mampu mengkonstruksi keragaman masyarakat adat dengan totalitas sosialnya ke dalam perundang-undangan. Kedua tidak ada kemauan politik dari pemerintah untuk membuat aturan yang menguatkan keberadaan masyarakt adat.

Wilayah kehidupan masyarakat hukum adat ini dalam kepustakaan disebut dengan hak ulayat (beschikking recht). Ulayat artinya wilayah. Hak ulayat adalah serangkaian wewenang dan kewajiban bagi masyarakat hukum adat, yang berhubungan dengan tanah yang ada dalam wilayah atau lingkungannya. Wewenang dan kewajiban tersebut ada yang masuk dalam ranah hukum Perdata/privat misalnya hak bersama atas tanah yang mereka huni, dan ada juga yang masuk dalam wilayah hukum umum atau publik berupa kewenangan untuk menata dan mengelola, mengatur dan menentukan peruntukan, penguasaan, penggunaan dan pemeliharaan atas sumber daya agraria dalam wilayah hak ulayat tersebut. ${ }^{23}$

Benturan makna atas tanah muncul ketika saling berhadapannya ipso jure versus ipso facto. Ipso jure yang berasal dari konsep hukum barat berhadapan dengan ipso facto yang berasal dari konsep hukum adat. Secara juridis (ipso jure); masyarakat dianggap sebagai pemilik sah atas tanah jika ia sebagai subjek hukum dapat membuktikannya dengan alat bukti hukum berupa surat sertifikat. Tetapi secara ipso facto, masyarakat menganggap bahwa ia memiliki sebidang tanah tidak dibuktikan melalui ada atau tidak adanya surat bukti kepemilikan berupa sertifikat tanah, tetapi dari hubungan intensif yang terjadi antara manusia dengan tanah dan pengakuan masyarakat sekitarnya. ${ }^{24}$ Semakin intens suatu masyarakat

${ }^{21}$ Ronald Z. Titahelu. "Penetapan Asas-Asas Hukum Umum dalam Penggunaan Tanah Untuk Sebesar-Besarnya Kemakmuran Rakyat Suatu Kajian Filsafat dan Teoritik Tentang Pengaturan dan Penggunaan Tanah Di Indonesia." Disertasi Doktor. Surabaya : Program Pascasarjana Universitas Airlangga, 1993, hlm. 75

22 Mukmin Zakie, "Perlindungan Hak atas Tanah Masyarakat Hukum Adat dalam Konstitusi," Jurnal Konstitusi, PSHK FH UII, Vol. II, No. 2, 2009, hlm. 119-139.

23 Boedi Harsono, Hukum Agraria Indonesia: Sejarah Pembentukan Undang-Undang Pokok Agraria, Isi dan Pelaksanaannya, Ed. Revisi, Djambatan, Jakarta, 2003, hlm. 180

${ }^{24}$ Mukmin Zakie, "Tanah dan Potensi Konflik Tiada Akhir," Makalah disampaikan pada "Pelatihan Penanganan Sengketa Agraria: Eksistensi Tanah Ulayat Di Wilayah Pertambangan, Kehutanan Dan Perkebunan Serta Potensi Konflik, 
berhubungan dengan tanah, maka pengakuan atas kepemilikan tanah tersebut akan semakin kuat.

\section{Pengertian Konflik}

Konflik pertanahan merupakan persoalan yang kronis dan bersifat klasik serta berlangsung dalam kurun waktu tahunan bahkan puluhan tahun dan selalu ada dimana-mana. Sengketa dan konflik pertanahan adalah bentuk permasalahan yang sifatnya kompleks dan multi dimensi. Oleh karena itu usaha pencegahan, penanganan dan penyelesaiannya harus memperhitungkan berbagai aspek baik hukum maupun non hukum. Seringkali penanganan dan penyelesaian terhadap sengketa dan konflik pertanahan dihadapkan pada dilema-dilema antara berbagai kepentingan yang sama-sama penting. Mencari keseimbangan atau win-win solution atas konflik yang sudah terjadi jelas membutuhkan upaya yang tidak mudah. Karena itu dibutuhkan pemahaman mengenai akar konflik, faktor pendukung dan faktor pencetusnya sehingga dapat dirumuskan strategi dan solusinya. Dengan usaha-usaha penyelesaian akar masalah, diharapkan sengketa dan konflik pertanahan dapat ditekan semaksimal mungkin, sekaligus menciptakan suasana kondusif dan terwujudnya kepastian hukum dan keadilan agraria yang mensejahterakan. ${ }^{25}$

Konflik berasal dari kata kerja Latin configere yang berarti saling memukul. Secara sosiologis, konflik diartikan sebagai suatu proses sosial antara dua orang atau lebih (bisa juga kelompok) dimana salah satu pihak berusaha menyingkirkan pihak lain dengan menghancurkannya atau membuatnya tidak berdaya. Konflik dapat juga dikatakan sebagai suatu bentuk interaksi sosial ketika dua individu mempunyai kepentingan yang berbeda dan kehilangan keharmonisan di antara mereka. Pada dasarnya konflik merupakan hal yang alamiah dan sering terjadi dalam kehidupan sehari-hari. ${ }^{26}$

Konflik menurut Susetiawan ${ }^{27}$ akan terjadi apabila sebuah kelompok berjuang untuk membela kepentingan-kepentingannya. Dalam terminologi Hobbesian juga dalam Susetiawan, konflik, untuk keuntungan, keamanan ataupun kejayaan, hanya akan berhenti dalam kematian. Max Weber mendemonstrasikan bahwa konflik tidak dapat dikeluarkan dari kehidupan sosial. Perdamaian tidak lebih dari sebuah perubahan dalam bentuk konflik atau dalam hal antagonis atau objek konflik, atau pada akhirnya dalam kesempatan seleksi. ${ }^{28}$ Dahrendorf menyatakan bahwa seluruh kehidupan sosial adalah konflik, karena ia merupakan perubahan. ${ }^{29}$

Sengketa Dan Penyelesaian Permasalahannya. Diselenggarakan oleh Good Governance Support (GGS), All Seasons Hotel, Yogyakarta, 16- - 17 Maret 2012.

25 Sumarto, Penanganan dan Penyelesaian Konflik Pertanahan Dengan Prinsip Win Win Solution Oleh Badan Pertanahan Nasional RI, Direktorat Konflik Pertanahan Badan Pertanahan Nasional RI 2012, Makalah, hlm. 1

${ }^{26}$ Basri, dan Nurhamlin "Konflik Masyarakat dan Perusahaan Perkebunan Serta Alternatif Penyelesaiannya di Kabupaten Rokan Hulu" Disampaikan pada Konferensi Nasional Sosiologi I "Asosiasi Program Studi Sosiologi di Indonesia" di Palembang, 2013, hlm. 7

27 Susetiawan, Konflik Sosial Kajian Sosiologis hubungan Buruh, Perusahaan dan Negara di Indonesia, Pustaka Pelajar Offset, Yogyakarta. 2000, hlm. 32

28 Max Weber, Etika Protestan dan Spirit Kapitalisme: Sejarah kemunculan dan Ramalan tentang Perkembangan Industrial Kontemporer Secara Menyeluruh, Pustaka Pelajar, Yogyakarta, 2006, hlm. 75

29 Ralf Dahrendorf, Konflik dan Konflik dalam Masyarakat Industri: Sebuah Analisa Kritik. Rajawali Press, Jakarta, 1986, hlm. 142 
Sengketa atau konflik merupakan suatu yang menjadi bagian dari kehidupan manusia sebagai makhluk sosial yang berinteraksi dengan sesamanya. Konflik bukan sesuatu yang harus dihindari tetapi dihadapi melalui pengenalan dan kemampuan mengelola secara baik dan benar. Konflik menjadi bagian penting yang kerap kali dihadapi ketika berinteraksi dalam masyarakat. Para ahli, praktisi dan akademisi memiliki cara pandangan yang beragam dalam memahami konflik. Berikut dikemukakan beberapa pengertian konflik;

Konflik merupakan warisan kehidupan sosial yang dapat berlaku dalam berbagai keadaan akibat dari berbangkitnya keadaan ketidak-setujuan, kontroversi dan pertentangan di antara dua pihak atau lebih pihak secara berterusan. ${ }^{30}$

Konflik merupakan ekspresi pertikaian antara individu dengan individu lain, kelompok dengan kelompok lain karena beberapa alasan. Dalam pandangan ini, pertikaian menunjukkan adanya perbedaan antara dua atau lebih individu yang diekspresikan, diingat, dan dialami. ${ }^{31}$

Dari beberapa pengertian konflik yang disampaikan pakar di atas, dapat ditarik kesimpulan bahwa Konflik adalah proses yang dinamis dan keberadaannya lebih banyak menyangkut persepsi dari orang atau pihak yang mengalami dan merasakannya. Dengan demikian jika suatu keadaan tidak dirasakan sebagai konflik, maka pada dasarnya konflik tersebut tidak ada dan begitu juga sebaliknya.

\section{Pengertian Sengketa/ Konflik Agraria}

Konflik pertanahan dapat diartikan sebagai konflik yang lahir sebagai akibat adanya hubungan antar orang atau kelompok yang terkait dengan masalah bumi dan segala kekayaan alam yang terdapat di atas permukaan maupun di dalam perut bumi. Istilah sengketa dan konflik pertanahan sering kali dipakai sebagai suatu padanan kata yang dianggap mempunyai makna yang sama. Akan tetapi sesungguhnya kedua istilah itu memiliki karakteristik yang berbeda.

Berdasarkan Peraturan Kepala BPN RI Nomor 3 Tahun 2011 tentang Pengelolaan Pengkajian dan Penanganan Kasus Pertanahan, Badan Pertanahan Nasional RI memberi batasan mengenai sengketa, konflik maupun perkara pertanahan. Pasal 1 Peraturan Kepala BPN tersebut menyatakan bahwa kasus pertanahan adalah sengketa, konflik dan perkara pertanahan yang disampaikan kepada Badan Pertanahan Nasional Republik Indonesia untuk mendapatkan penanganan, penyelesaian sesuai peraturan perundang-undangan dan/atau kebijakan pertanahan nasional.

a. Sengketa Pertanahan.

Sengketa pertanahan adalah perselisihan pertanahan antara orang perseorangan, badan hukum atau lembaga yang tidak berdampak luas secara sosio-politis. Penekanan yang tidak berdampak luas inilah yang membedakan definisi sengketa pertanahan dengan

30 Taquiri dalam Newstorm dan Davis, dikutip dari Ahmad Ubbe, Laporan Pengkajian Hukum Tentang Mekanisme Penanganan Konflik Sosial, Pusat Penelitian dan Pengembangan Sistem Hukum Nasional Badan Pembinaan Hukum Nasional Kementerian Hukum dan HAM RI, Jakarta, 2011, hlm. 12

31 R Wayne Pace, dan Don F Faules,. Terjemahan. Komunikasi Organisasi: Strategi Meningkatkan Kinerja Perusahaan. Remaja Rosdakarya, Bandung, 2005, hlm. 249. 
definisi konflik pertanahan. Sengketa tanah dapat berupa sengketa administratif, sengketa perdata, sengketa pidana terkait dengan pemilikan, transaksi, pendaftaran, penjaminan, pemanfaatan, penguasaan dan sengketa hak ulayat.

b. Konflik Pertanahan.

Konflik pertanahan merupakan perselisihan pertanahan antara orang perseorangan, kelompok, golongan, organisasi, badan hukum atau lembaga yang mempunyai kecenderungan atau sudah berdampak luas secara sosio politis.

c. Perkara Pertanahan.

Perkara pertanahan adalah perselisihan pertanahan yang penyelesaiannya dilaksanakan oleh lembaga peradilan atau putusan lembaga peradilan yang masih dimintakan penanganan perselisihannya di BPN RI.

\section{Akar Konflik Pertanahan.}

Akar konflik pertanahan merupakan faktor mendasar yang menyebabkan timbulnya konflik pertanahan. Akar konflik pertanahan penting untuk diidentifikasi serta diinventarisasi guna mencari jalan keluar atau bentuk penyelesaian yang akan dilakukan.

Penyebab umum timbulnya konflik pertanahan dapat dikelompokkan dalam dua faktor, yaitu faktor hukum dan faktor non hukum. ${ }^{32}$

a. Faktor Hukum

Beberapa faktor hukum yang menjadi akar dari konflik pertanahan belakangan ini antara lain :

1) Tumpang tindih peraturan.

UUPA sebagai induk dari peraturan di bidang sumber daya agraria lainnya, dalam perjalanannya dibuat beberapa peraturan perundang-undangan yang berkaitan dengan sumber daya agraria tetapi tidak menempatkan UUPA sebagai undangundang induknya, bahkan justru menempatkan UUPA sejajar dengan undang-undang agraria. UUPA yang mulanya merupakan payung hukum bagi kebijakan pertanahan di Indonesia menjadi tidak berfungsi dan secara substansial bertentangan dengan diterbitkannya berbagai peraturan perundangan sektoral seperti UU Kehutanan, UU Pertambangan, UU Transmigrasi dan lain-lain.

2) Tumpang tindih peradilan.

Pada saat ini terdapat tiga lembaga peradilan yang dapat menangani suatu konflik pertanahan yaitu peradilan perdata, peradilan pidana dan peradilan tata usaha negara (TUN). Dalam bentuk konflik tertentu, salah satu pihak yang menang secara perdata belum tentu menang secara pidana (dalam hal konflik disertai tindak pidana).

32 Bernhard Limbong, Konflik Pertanahan, Pustaka Margaretha, Jakarta, 2012, hlm. 66 -70 
b. Faktor Non Hukum ${ }^{33}$

1) Tumpang tindih penggunaan tanah.

Sejalan dengan waktu, pertumbuhan penduduk yang cepat mengakibatkan jumlah penduduk bertambah, sedangkan produksi pangan tetap atau mungkin berkurang karena banyak tanah pertanian yang beralih fungsi. Tidak dapat dihindarkan bahwa dalam sebidang tanah yang sama dapat timbul kepentingan yang berbeda.

2) Nilai ekonomis tanah tinggi

Ada anggapan disamping emas, nilai tanah dari waktu ke waktu akan semakin tinggi, sehingga untuk memperoleh tanah semakin sulit.

3) Kesadaran masyarakat meningkat

Adanya perkembangan global serta peningkatan perkembangan ilmu pengetahuan dan teknologi berpengaruh pada peningkatan kesadaran masyarakat. Pola pikir masyarakat terhadap masyarakatpun ikut berubah. Terkait tanah sebagai aset pembangunan, maka muncul perubahan pola pikir masyarakat terhadap penguasaan tanah, yaitu tidak lagi menempatkan tanah sebagai sumber produksi akan tetapi menjadikan tanah sebagai sarana untuk investasi atau komoditas ekonomi.

4) Tanah tetap, penduduk bertambah.

Pertumbuhan penduduk yang sangat cepat baik melalui kelahiran maupun migrasi serta urbanisasi, serta jumlah lahan yang tetap, menjadikan tanah sebagai komoditas ekonomi yang nilainya sangat tinggi, sehingga setiap jengkal tanah dipertahankan sekuatnya.

5) Kemiskinan.

Kemiskinan merupakan masalah kompleks yang dipengaruhi oleh berbagai faktor yang saling berkaitan. Terbatasnya akses terhadap tanah merupakan salah satu faktor penyebab kemiskinan dalam kaitan terbatasnya aset dan sumber daya produktif yang dapat diakses masyarakat miskin.

\section{Tipologi Konflik Pertanahan.}

Tipologi konflik pertanahan merupakan jenis sengketa, konflik dan atau perkara pertanahan yang disampaikan atau diadukan dan ditangani. Tipologi konflik pertanahan yang ditangani Badan Pertanahan Nasional RI dapat dikelompokkan menjadi 8 (delapan), terdiri dari masalah yang berkaitan dengan: ${ }^{34}$

33 Sumarto, "Penanganan Dan Penyelesaian Konflik Pertanahan Dengan Prinsip Win Win Solution " Oleh Badan Pertanahan Nasional RI, Direktorat Konflik Pertanahan Badan Pertanahan Nasional RI 2012,” Makalah, Jakarta, hlm. 5

34 ibid, hlm. 6 
a. Penguasaan dan Pemilikan Tanah, yaitu perbedaan persepsi, nilai atau pendapat, kepentingan mengenai status penguasaan di atas tanah tertentu yang tidak atau belum dilekati hak (tanah negara), maupun yang telah dilekati hak oleh pihak tertentu;

b. Penetapan Hak dan Pendaftaran Tanah, yaitu perbedaan persepsi, nilai atau pendapat, kepentingan mengenai proses penetapan hak dan pendaftaran tanah yang merugikan pihak lain sehingga menimbuikan anggapan tidak sahnya penetapan atau perijinan di bidang pertanahan;

c. Batas atau letak bidang tanah, yaitu perbedaan pendapat, nilai kepentingan mengenai letak, batas dan luas bidang tanah yang diakui satu pihak yang teiah ditetapkan oleh Badan Pertanahan Nasional Republik Indonesia maupun yang masih dalam proses penetapan batas;

d. Pengadaan Tanah, yaitu perbedaan pendapat, kepentingan, persepsi atau nilai mengenai status hak tanah yang perolehannya berasal proses pengadaan tanah, atau mengenai keabsahan proses, pelaksanaan pelepasan atau pengadaan tanah dan ganti rugi;

e. Tanah obyek Landreform, yaitu perbedaan persepsi, nilai atau pendapat, kepentingan mengenai prosedur penegasan, status penguasaan dan pemilikan, proses penetapan ganti rugi, penentuan subyek obyek dan pembagian tanah obyek Landreform;

f. Tuntutan Ganti Rugi Tanah Partikelir, yaitu perbedaan persepsi, pendapat, kepentingan atau nilai mengenai Keputusan tentang kesediaan pemerintah untuk memberikan ganti kerugian atas tanah partikelir yang dilikwidasi;

g. Tanah Ulayat, yaitu perbedaan persepsi, nilai atau pendapat, kepentingan mengenai status ulayat dan masyarakat hukum adat di atas areal tertentu baik yang telah diterbitkan hak atas tanah maupun yang belum, akan tetapi dikuasai oleh pihak lain;

h. Pelaksanaan Putusan Pengadilan, yaitu perbedaan persepsi, nilai atau pendapat, kepentingan mengenai putusan badan peradilan yang berkaitan dengan subyek atau obyek hak atas tanah atau mengenai prosedur penerbitan hak atas tanah tertentu.

Jika diamati secara seksama, apa yang pernah diidentifikasi oleh pengkaji pertaanahan sebelumnya terkaait dengan sengketa agrarian, dalam beberapa hal ada benarnya. Misalnya saja, Maria SW Sumardjono menegaskan bahwa berbagai konflik agraria diakibatkan oleh adanya penggarapan tanah yang menjadi areal kehutanan atau perkebunan oleh rakyat, adanya pelanggaran terhadaap ketentuan ladreform, adanya upaya penyediaan lahan untuk kepentingan pembangunan, serta, karena adanya berbagai masalah perdata. ${ }^{35}$

Hal penting lain yang perlu dicatat dalam masalah karakteristik sengketa agraria ini adalah bahwa telah terjadi pergeseran pola antara masa pasca kemerdekaan hingga era Orde Baru. Pada pasca kemerdekaan sampai dengan era akhir 1960 an, sengketa biasanya terjadi

\footnotetext{
35 Maria SW Sumardjono, Tanah Dalam Perspektif Hak Ekonomi Sosial dan Budaya, Penerbit Buku Kompas, Jakarta, 2008, hlm. 109
} 
pada di pedesaan antara petani penggarap dengan penguasa tanah. Sedangkan pada decade 1980 sampai dengan akhir Orde Baru sengketa terjadi antara pemilik tanah setempat melawan pemodal besar atau pemerintah. ${ }^{36}$ Akan tetapi, berdasarkan penelitian ini didapatkan bahwa pada masa reformasi, sengketa berupa rakyat penggarap melawan pemerintah atau industry dengan posisi rakyat yang sangat menguat, dimana penjarahan tanah banyak terjadi.

Di samping itu, dalam berbagai sengketa agraria, terdapat berbagai unsur yang acapkali terlibat di dalamnya, utamanya adalah:

a. Adanya aktor ekonomi, aktor politik ataupun aktor sosial yang kuat

b. Administrasi yang bermasalah, termasuk di dalamnya proses ajudikasi yang tidak tertata baik.

c. Melibatkan warga masyarakat yang sangat awam terhadaap hokum positif namun dalam realitanya sudah menguasai tanah tersebut dalam waktu lama, dan bahkan secara turun temurun. Dan segmen ini biasanya sebagai korban. ${ }^{37}$ Adapun sebab yang lebih detail dari munculnya sengketa agraria adalah faktor-faktor seperti, Pertama, tidak meratanya distribusi pemanfaatan dari sumber daya agrarian yang ada. Kedua, ekspansi wilayah oleh suatu kelompok, dan ini lebih banyak terjadi di perkotaan. Ketiga, adalah adanya kegiatan ekonomi sebagian dari masyarakat. Tentu ini adalah kegiatan ekonomi yang dapat mengganggu masyarakat sekitarnya. Keempat, adanya kepadatan penduduk yang menuntut penyediaan lahan yang semakin luas. ${ }^{38}$

Jika dianalisa terkait posisi para pihak yang terlibat sengketa, maka ada konflik vertikal dalam arti konflik antara masyarakat dengan pemerintah atau pihak yang berwenang, horizontal ialah konflik antara satu masyarakat dengan masyarakat lainnya, dan konflik antara masyarakat melawan investor. ${ }^{39}$

\section{Karakteristik Sengketa Agraria Di Indonesia}

Telah disadari oleh para pendiri bangsa bahwa Negara Indonesia ini memiliki tingkat keragaman yang sangat tinggi, baik dari segi budaya, letak geografis maupun agama. Keberagaman yang semacam ini tentu bukan tanpa efek yang serius bagi perkembangan bangsa ke depannya. Karena itulah, pembangunan Negara ini tidak boleh hanya dilakukan dengan menggeneralisir berbagai faktor keragaman tersebut.

Karena itulah maka Negara dirumuskan sebagai terdiri atas Zelfbesturende landschappen dan Volksgemeenschappen di dalam UUD 1945 (sebelum amandemen). Menurut sebagian pendapat, langkah ini mempunyai dua sisi implikasi. Pertama dengan menyerap kekhasan tiap komunitas yang ada, maka negara telah berupaya menciptakan satu bangsa. Kedua,

\footnotetext{
${ }^{36}$ Marzuki, Suparman, Konflik Tanah di Indonesia, Pusat Studi HAM Universitas Islam Indonesia, 2008, <www. pusham.uii.ac.id> Diakses pada 17 September 2013

37 Mohd. Jully Fuady, Mencari Formula Penyelesaian Konflik dan Sengketa Pertanahan di Aceh.dalam <http://www.lbhaceh.org/> Diakses pada 17. Juli 2013

38 Asrul Ibrahim Nur, Anatomi Konflik Sosial dalam, <www.theindonesianinstitute.com.> Diakses pada 17.Juli 2013

39 Op cit.
} 
pengabaian terhadap eksistensi berbagai komunitas dengan segenar kekhasannya tersebut akan berimplikasi pada kegagalan cita-cita membangun satu bangsa Indonesia (Naskah Akademik RUU Perlindungan Masyarakat Adat, 2011).

Konflik tidaklah mungkin dapat dihindari, sebagaimana fakta yang ada bahwa konflik akan selalu ada dalam masyarakat. Satu-satunya cara yang dapat dilakukan, selain menyelesaikan konflik yang telah terjadi, adalah dengan mendeteksi lebih dini potensi konflik yang akan muncul, sehingga konflik tidak akan dapat direduksi ekses yang ditimbulkannya.

Dalam teori konflik, keberagaman jelas merupakan berkontribusi pada terjadinya perbedaan. Perbedaan tersebut merupakan elemen yang dapat mengakibatkan disintegrasi dan perubahan. ${ }^{40}$

Sengketa agraria merupakan suatu sengketa yang sangat sering terjadi dalam masyarakat, terlebih masyarakat Indonesia yang memang merupakan masyarakat agraris. Dari penelitian yang dilakukan, Nampak bahwa berbagai kasus sengketa agraria terjadi terkait dengan berbagai macam lahan pertanian, perkebunan, pertambangan ataupun lahan jenis lainnya.

\section{Simpulan}

Dari uraian di atas dapat diperoleh kesimpulan sebagai berikut:

1. Konflik pertanahan merupakan isu yang selalu muncul dan selalu aktual dari masa ke masa, seiring dengan bertambahnya penduduk, perkembangan pembangunan, dan semakin meluasnya akses berbagai pihak untuk memperoleh tanah sebagai modal dasar dalam berbagai kepentingan.

2. Berbagai konflik agraria muncul karena banyak faktor diakibatkan oleh: Pertama, tidak meratanya distribusi pemanfaatan dari sumber daya agraria yang ada. Kedua, ekspansi wilayah oleh suatu kelompok, dan ini lebih banyak terjadi di perkotaan. Ketiga, adalah adanya kegiatan ekonomi sebagian dari masyarakat. Tentu ini adalah kegiatan ekonomi yang dapat mengganggu masyarakat sekitarnya. Keempat, adanya kepadatan penduduk yang menuntut penyediaan lahan yang semakin luas.

3. Sebagai hak dasar, hak atas tanah sangat berarti sebagai tanda eksistensi, kebebasan, dan harkat diri seseorang. Di sisi lain, negara wajib memberi jaminan kepastian hukum terhadap hak atas tanah itu walaupun hak itu tidak bersifat mutlak karena dibatasi oleh kepentingan orang lain, masyarakat dan negara. Pada saat ini regulasi yang ada masih menunjukkan ada overlapping antara sektoral, lembaga yang mempunyai otoritas di bidang pengelolaan sumber daya agraria.

40 Erlita Kusumaningtiyas dan Kandyawan, Media Dan Penyajian Berita Rekonsiliasi (Studi Analisis Isi Penyajian Berita Rekonsiliasi dan Konflik Pasca Rekonsiliasi Keraton Kasunanan Surakarta di Surat Kabar Harian Solopos dan Suara Merdeka Periode Mei - Juni 2012) Program Studi Ilmu Komunikasi Fakultas Ilmu Sosial dan Ilmu Politik Universitas Sebelas Maret, 2012, hlm. 8 


\section{Daftar Pustaka}

Abdul Aziz Hussin, Undang-undang Tanah Lesen Pendudukan Sementara dan Permit, Dewan Bahasa dan Pustaka, Kuala Lumpur, Ctk. 1, 1996

Asrul Ibrahim Nur, Anatomi Konflik Sosial dalam, www.theindonesianinstitute. com. Diakses pada 17 Juli 2013

B. Ter Haar, Bzn, Terjemahan Schiller, A.A. \& E.A. Hoebel, 1962. Adat Law In Indonesia, Bharata.

Basri, dan Nurhamlin "Konflik Masyarakat dan Perusahaan Perkebunan Serta Alternatif Penyelesaiannya di Kabupaten Rokan Hulu" Disampaikan pada Konferensi Nasional Sosiologi I "Asosiasi Program Studi Sosiologi di Indonesia" di Palembang.

Bernhard Limbong, Konflik Pertanahan, Pustaka Margaretha, Jakarta, 2012.

Boedi Harsono, Hukum Agraria Indonesia: Sejarah Pembentukan Undang-Undang Pokok Agraria, Isi dan Pelaksanaannya, Ed. Revisi, Djambatan, Jakarta, 2003.

Chamhuri Siwar, 'Penyusunan Semula Masyarakat Melalui Reformasi Tanah' dalam ; Isu Ekonomi, Sosial Dan Politik Malaysia : Kumpulan Esei Dewan Masyarakat 19751979, Dewan Bahasa dan Pustaka Kementerian Pelajaran Malaysia, Kuala Lumpur, 1983.

Dianto Bachriadi, dan Anton Lucas, Merampas Tanah Rakyat,Kasus Tapos dan Cimacan, Kepustakaan Populer Gramedia, Jakarta, 2001.

Erlita Kusumaningtiyas dan Kandyawan, Media Dan Penyajian Berita Rekonsiliasi (Studi Analisis Isi Penyajian Berita Rekonsiliasi dan Konflik Pasca Rekonsiliasi Keraton Kasunanan Surakarta di Surat Kabar Harian Solopos dan Suara Merdeka Periode Mei - Juni 2012) Program Studi Ilmu Komunikasi Fakultas Ilmu Sosial dan Ilmu Politik Universitas Sebelas Maret, 2012.

Gatra News, 28 Januari 2012

Haedar Laudjeng, dan Arimbi. HP, Bayang-Bayang Culturstelsel dan Domein Verklaring dalam Praktik Politik Agraria, WALHI. Jakarta.

Hermayulis, 'Penerapan Hukum Pertanahan dan Pengaruhnya Terhadap Hubungan Kekerabatan Pada Sistem Kekerabatan Matrilineal Minangkabau Di Sumatera Barat', Disertasi, PPS-UI, 1999.

John Salindeho, Masalah Tanah Dalam Pembangunan, Sinar Grafika. Jakarta, 1987.

Kalo, Syafruddin. 'Di Bawah Cengkeraman Kapitalisme: Konflik Status Tanah Jaluran Antara Onderneming Dan Rakyat Penunggu Di Sumatra Timur Jaman Kolonial,' USU Digital Library. Diakses 10 Maret 2012. 
Kalo, Syafruddin. 'Perbedaan Persepsi Mengenai Penguasaan Tanah Dan Akibatnya Terhadap Masyarakat Petani Di Sumatera Timur: Pada Masa Kolonial Yang Berlanjut Pada Masa Kemerdekaan, Orde Baru Dan Reformasi,' USU Digital Library. Diakses 1 Maret 2012.

Kompas, 17 Desember 2011

Maria SW Sumardjono, Tanah Dalam Perspektif Hak Ekonomi Sosial dan Budaya, Penerbit Buku Kompas, Jakarta, 2008.

Marzuki, Suparman, Konflik Tanah di Indonesia, Pusat Studi HAM Universitas Islam Indonesia, 2008, <www.pusham.uii.ac.id> Diakses pada 17 September 2013

Max Weber, Etika Protestan dan Spirit Kapitalisme: Sejarah kemunculan dan Ramalan tentang Perkembangan Industrial Kontemporer Secara Menyeluruh, Pustaka Pelajar, Yogyakarta, 2006.

Mohd. Jully Fuady, Mencari Formula Penyelesaian Konflik dan Sengketa Pertanahan di Aceh, dalam http://www.lbhaceh.org/ Diakses pada 17 Juli 2013

Mukmin Zakie, "Perlindungan Hak atas Tanah Masyarakat Hukum Adat dalam Konstitusi", Jurnal Konstitusi, PSHK FH UII, Vol. II, No. 2, 2009.

Mukmin Zakie, "Tanah dan Potensi Konflik Tiada Akhir," Makalah disampaikan pada "Pelatihan Penanganan Sengketa Agraria: Eksistensi Tanah Ulayat Di Wilayah Pertambangan, Kehutanan Dan Perkebunan Serta Potensi Konflik, Sengketa Dan Penyelesaian Permasalahannya. Diselenggarakan oleh Good Governance Support (GGS), All Seasons Hotel, Yogyakarta, 16- - 17 Maret 2012.

Mukmin Zakie, "Undang-Undang Pengambilan Tanah Di Indonesia Dan Di Malaysia (Suatu Kajian Perbandingan)", Desertasi Doktor Falsafah Fakulti Undang-Undang, Universiti Kebangsaan Malaysia, 2011.

Mukmin Zakie, Kewenangan Negara dalam Pengadaan Tanah bagi Kepentingan umum di Indonesia dan Malaysia, Buku Litera Yogyakarta, 2013.

Noer Fauzi, Bersaksi untuk Pembaharuan Agraria, dari Tuntutan Lokal hingga Kecenderungan Global, Insist Press, Yogyakarta, 2003.

Perlembagaan Persekutuan, Seksyen 2 Senarai II-Senarai Negeri, lih Kanun Tanah Negara 1965, seksyen 40.

R Wayne Pace, dan Don F Faules,. Terjemahan. Komunikasi Organisasi: Strategi Meningkatkan Kinerja Perusahaan. Remaja Rosdakarya, Bandung, 2005.

Ralf Dahrendorf, Konflik dan Konflik dalam Masyarakat Industri: Sebuah Analisa Kritik. Rajawali, Jakarta, 1986.

Releigh Barlowe, Land Resource Economics: The Economics of Real Estate, Prentice-Hall Inc. New Jersey, 1978. 
Republika, 14 Desember 2011

Ronald Z. Titahelu. "Penetapan Asas-Asas Hukum Umum dalam Penggunaan Tanah Untuk Sebesar-Besarnya Kemakmuran Rakyat Suatu Kajian Filsafat dan Teoritik Tentang Pengaturan dan Penggunaan Tanah Di Indonesia." Disertasi Doktor. Surabaya: Program Pascasarjana Universitas Airlangga, 1993.

Sumarto, "Penanganan Dan Penyelesaian Konflik Pertanahan Dengan Prinsip Win Win Solution "Oleh Badan Pertanahan Nasional RI, Direktorat Konflik Pertanahan Badan Pertanahan Nasional RI 2012,” Makalah, Jakarta.

Sumarto, Penanganan dan Penyelesaian Konflik Pertanahan Dengan Prinsip Win Win Solution Oleh Badan Pertanahan Nasional RI, Direktorat Konflik Pertanahan Badan Pertanahan Nasional RI 2012, Makalah.

Susetiawan, Konflik Sosial Kajian Sosiologis hubungan Buruh, Perusahaan dan Negara di Indonesia. Pustaka Pelajar Offset, Yogyakarta. 2000.

Taquiri dalam Newstorm dan Davis, dikutip dari Ahmad Ubbe, Laporan Pengkajian Hukum Tentang Mekanisme Penanganan Konflik Sosial, Pusat Penelitian dan Pengembangan Sistem Hukum Nasional Badan Pembinaan Hukum Nasional Kementerian Hukum dan HAM RI, Jakarta, 2011. 